\title{
RESEARCH PAPER \\ ECONOMIC DIMENSIONS OF TONO AND VEA INLAND FISHERIES OF THE UPPER EAST REGION OF GHANA
}

\author{
M. Okrah ${ }^{1}$ and K. O. Agyeman ${ }^{2}$ \\ ${ }^{I}$ Department of Planning and Management, University for Development Studies, Tamale, Ghana \\ Email:okmax2011@yahoo.com \\ ${ }^{2}$ Department of Planning, KNUST, Kumasi. \\ Email: kwasi.1955@yahoo.co.uk
}

\begin{abstract}
This research sought to explore and understand the contribution of the fishery subsector of the Tono and Vea irrigation projects within the context of employment, income and revenue generations. The central argument of the study is that the continuous investment and appropriation of the fishery resources is being guided by an access regime in operation. Adopting a case study design, it triangulated both secondary and primary sources of data for effective analysis. Through random and systematic sampling, 192 fishermen and fishmongers were selected for the study. Structured and semi-structured interview techniques were used to solicit views from primary sources and complemented with relevant secondary documents from the organisations investigated (ICOUR and MoFA). Empirical results revealed that the access regime to the fishery was significantly open access and growth in the profit variable of the fishery was more induced by tonnes of fish catch than price. The fishery can play its proper role of improving upon direct and ancillary fishery income and employment when the 'livelihood approach' is used to value the river fisheries and the ecosystem for sustainable rural livelihoods.
\end{abstract}

Keywords: Inland Fishery, Revenue, Employment, Income, Open Access,

\section{INTRODUCTION}

The small-scale fisheries sub-sector serves as a source of income, employment and food to many households in African. Apart from actual fishing, other fishing related activities like fish processing, marketing, boat building and basket weaving are important sources of income and household support livelihood activity for many. Women are key players in these ancillary activities (Njaya, 2007). This sector provides people with an important and sometimes crucial form of safety-net that helps protect them against the effects of agricultural product price volatility, macro-economic crises, structural reforms, harvest failures and other factors that threaten rural stability and food security (FAO, 1996; cited in Sarch and Allison, 2000).

Allison et al. (2007) argued that during high production periods at Lake Chilwa, the inland fisheries contribute readily-earned cash to the wider rural economy. In supporting this view, Béné (2006) pointed out that a well managed inland fisheries and fish-related activities play a critical role in generating wealth and sustaining economic growth. For example, research in the 


\section{Okrah and Agyeman}

Zambezi area reveals that inland fisheries generate more cash for households than cattle rearing in most cases and more than crop production in some cases. This confirms the assertion by Lorenzen et al. (2000) that, about 30\% of rural households' income in Laos is earned through inland fishing. According to World Fish Centre (2008), inland fisheries of West and Central Africa are not only labour intensive and artisanal but also strategies of riskspreading and provision of subsistence income for the poor rural households. However, over reliance on the economic value to the neglect of sustainability is a potential for overfishing (Von Sarnowski (2004) as the biotic productivity of inland fishery is driven by seasonal flooding (Junk et al., 1989; cited in Béné, 2007). In Ghana, the Ministry of Food and Agriculture (2002) admitted that the fisheries sub-sector contributes $5 \%$ of the agricultural share of GDP and $3 \%$ of national GDP.

Inland fisheries were acknowledged to be great provider of employment to many households especially in developing countries (COFAD, 2002; Allan et al., 2005). This was later supported by the study of Neiland and Béné (2003) that, the fisheries of river basins of West and Central Africa provide employment to as many as 64,700 and 62,000 households in the NigerBenue system and in the Congo-Zaire respectively. In spite of a high record of net losses of employment in recent times, the inland fishery sector in Ghana employs about 80,000 fishers and some 20,000 fish processors (MoFA, 2008). Although livelihoods of fisherfolk are known to be adaptive (mobile, seasonal and diverse), long-term decline in fishing is a wider concern for rural development because fisheries provide one of the few sources of cash revenue and are therefore a local "engine of growth" in areas otherwise remote from the cash economy (Allison et al., 2004). Also, a study at Lake Chariba by Njaya (2007) supports the revenue attribute of inland fisheries as the collection of taxes from fishers and traders (appropriators of the commons) provided revenue for the common good of all communities around the fish- ing area.

Given the economic importance of the sector, it is no surprise that the government of Ghana funded the construction of irrigation projects around the country, including the Tono and Vea irrigation projects. The choice of Upper East Region for the construction of the Tono dam, Vea dam and other small-scale dams has been influenced by irrigation potentials. The aim was to strengthen the Irrigation Company of Upper Region (ICOUR) in the development of livestock, crops and fisheries of Tono and Yaritanga rivers (ICOUR, 1995). As acknowledged by Hardin (1968; cited in Hartmann et al., 2004) the users of common-pool resources are caught in an inevitable process that leads to the destruction of the very resources on which they depend. The open access fisheries of Tono and Vea have been recording fluctuations in catch over the past ten (10) years, spanning 2000 to 2009. This therefore throws a challenge to the economic benefits of employment, revenue and income generations of the Tono and Vea reservoirs fisheries.

The focus of this paper is therefore to assess the contribution of the fishery subsector of Tono and Vea irrigation projects to employment, income and revenue generation as well as poverty reduction in the catchment Districts.

\section{MATERIALS AND METHODS}

The study employed a case study approach which combined the relevant aspects of quantitative and qualitative data for a better understanding of how the inland fisheries of the Tono and Vea reservoirs have contributed to employment, income and revenue of the catchment Districts (Kassena Nankana and Bongo Districts). With a registered fishermen and fishmonger's population of 382 (245 fishermen and 137 fishmongers), about 50\% (192) of them were sampled through a systematic sampling technique. Structured interviews were used to elicit data from the respondents on the variables of fishery income, employment, catch, revenue and fishing revenue. 
Economic Dimensions of Inland Fisheries... 132

A semi-structured interview guide was also employed to seek specialised knowledge and views from 'key persons' on the dynamics of the inland fisheries of Tono and Vea reservoirs. Triangulating sources and data, qualitative and quantitative methods were used to analyse the data. Qualitative analysis took the form of interpreting specicialised views and content analysis of interviews and documents, while quantitative analysis took the form of descriptive statistics such as correlations, frequencies and percentages, supported with relevant tables and graphs. The study focused on the Upper East Region of Ghana which has a large number of small reservoirs, 160 in number (Leibe $e t$ al., 2005) with Tono and Vea being the biggest. Aside displaying the potential for crop production, the Tono and Vea reservoirs also exhibit additional characteristics of facilitating the harvesting of inland fish under the management of ICOUR. To clearly establish the economic impacts of the reservoir fisheries, fishermen and fishmongers, who had registered with the Irrigation Company of the Upper Region (ICOUR) were sampled for the survey (See Table 1).

\section{RESULTS AND DISCUSSIONS}

The nature of access to harvest or buy fish stock from the Tono and Vea reservoirs are identified and presented in Fig. 1. This analysis covers the views of the sampled fishermen and fishmongers (192). In spite of the openness of access $(81 \%$ and $97.1 \%$ of fishermen and fishmongers respectively), registration is required of the users. However, $13 \%$ of the fishermen perceived their entry to the fishery to be limited as management always enforce the compliance and observation of closed season and restriction on gear quantity and size. The study revealed that about $2 \%$ and $2.9 \%$ of the fishermen and fishmongers respectively, did not go through the basic requirement of registration either with ICOUR or MoFA before having direct or ancillary access to the fishery. This category of users acknowledged their entry to be illegal hence they normally operate in the night and early hours of the day.

Prior to the construction of the Tono and the Vea irrigation dams, River Tono and Yarigatanga were being used as a common property where the rules do not exist or were not enforced to limit the use of the resource. However, the current study clearly indicates the existence of open access fishery but the choice of entry was not influenced by price of entry and/or the expected returns. This is at variance with the findings of Baland and Platteau (2000). The integration of common property regime with open access condition created a situation of overfishing and decline in the size of fish (Von Sarnowski, 2004). Clearly, the study shows the existence of open access situation but the users need to be regulated by

Table 1: Number of fishermen and fishmongers surveyed

\begin{tabular}{lllll}
\hline $\begin{array}{l}\text { Category of } \\
\text { Respondent }\end{array}$ & Reservoir & Sample Frame & Sample Size & Coverage \\
\hline \multirow{2}{*}{ Fishermen } & Tono & 183 & 92 & $50 \%$ \\
& Vea & 62 & 31 & $50 \%$ \\
& Total (A) & 245 & 123 & $50 \%$ \\
\multirow{4}{*}{ Fishmongers } & Tono & 117 & 59 & $50 \%$ \\
& Vea & 20 & 10 & $50 \%$ \\
\multirow{2}{*}{ Grand Total (A+B) } & Total (B) & 137 & 69 & $50 \%$ \\
\hline
\end{tabular}

Source: Field Survey, 2011 


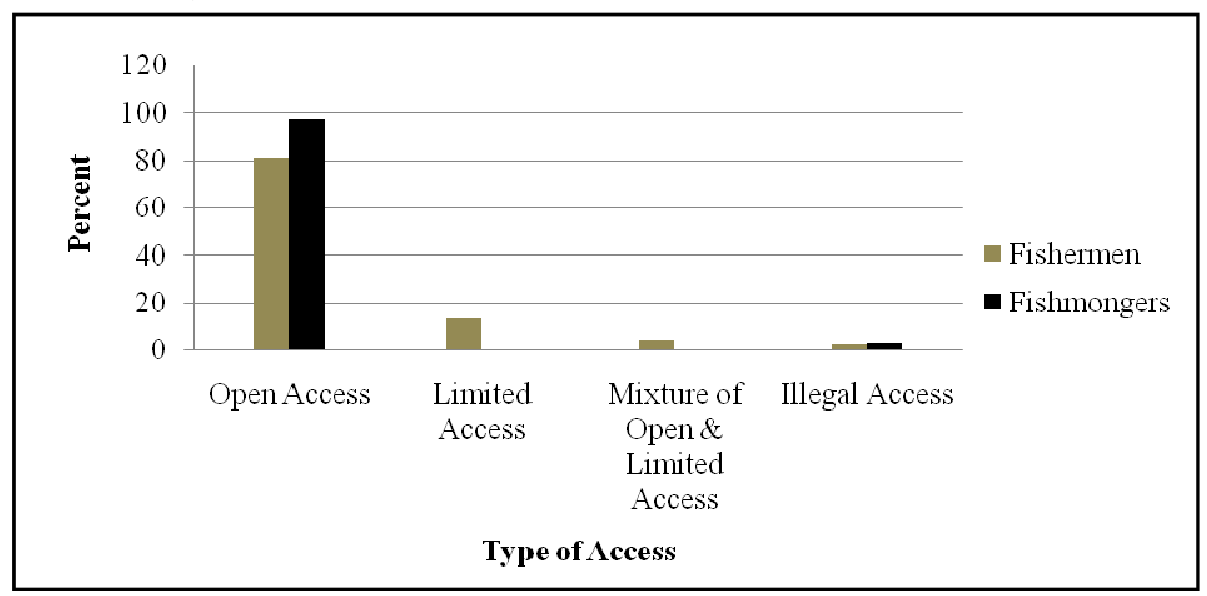

Fig. 1: Assessment of access to the fishery of the Tono and Vea Reservoirs

ICOUR and/or MoFA to ensure economic efficiency. However, the open access condition has the potential of giving rise to insufficient law enforcement, increase investment and fishing effort.

Table 2 depicts the proportion of fishermen and fishmongers who are employed by the inland fisheries of Tono and Vea reservoirs. The employment generated has been primarily classified into direct (i.e. registered users) and ancillary/indirect (those who have not registered but earn a livelihood from the fishery). Directly, $64 \%$ and $36 \%$ of the registered fishermen and fishmongers were employed in the fishery. The 'trickle-down' effect of fishery was that, 248 people within the catchment of the reservoirs gained ancillary employment. Out of this number (248), 74\% were generated by the fisher- men while, $26 \%$ came from the fishmongers. Comparing fishery employment with the potential labour force of the study Districts, $0.43 \%$ of the labour force were directly and indirectly employed in the fishery.

In rural areas where job options are limited, fishing and its related activities serve as a crucial source of livelihoods for low-income families in developing nations. The ancillary activities and employment include net repairs, boat making, basket weaving and the sale of fishing gear (Kura et al., 2004; cited in Allan et al., 2005). As a characteristic of the informal sector, the ancillary employment component of the fishery employment is mostly given a marginal consideration (COFAD, 2002).

The current study shows a minimal contribution

Table 2: Direct and ancillary inland fishery employment as at the year 2000

\begin{tabular}{llll}
\hline Category & Fishermen & Fishmongers & Total \\
\hline Potential labour force & $67,414(46)$ & $79,193(54)$ & 146,607 \\
Direct employment (A) & $245(64)$ & $137(36)$ & 382 \\
Ancillary/indirect employment (B) & $183(74)$ & $65(26)$ & 248 \\
$\begin{array}{l}\text { Aggregate employment (A+B) } \\
\begin{array}{l}\text { Percentage of fishery employment to potential labour } \\
\text { force }\end{array}\end{array}$ & $428(68)$ & $202(32)$ & 630 \\
\hline
\end{tabular}

Source: Adapted from Ghana Statistical Service (2000)

*Potential labour force was classified from the male and female age groups of 15-64 years* 
Economic Dimensions of Inland Fisheries... 134

of the Tono and Vea inland fisheries subsector to employment. Fishermen, especially those from the Vea reservoir, acknowledged that the employment function of the fishery could be extended to food sellers who use fish as their input. There was a male predominance in both direct and ancillary fishery-related activities and employment. While fishmongers did not perceive the engagement of the services of others, especially women, as employment, it was unequivocal among the fishermen and fishmongers that the ability to sustain and create future fishery employment was the function of adequate rainfall and increase in catch related mortality of fish. Aside the proportion of employment generation of $0.43 \%$, the fishery has a 'trickle-down' effect on ancillary employment which could translate into income and other economic benefits. This is similar to the findings of Junk et al. (1989; cited in Béné, 2007). Thus, improvement upon fishery employment requires the conservation of the fish stock since the common denominator in fishery employment is fish.

Fishery mortality as a result of fishing is mostly used to assess the level of income and the income level is also directly related to the tonnes of fish catch. To assess this view, the relationship between/among tonnes of fish catch, price per tonne and profit was examined. Among these variables, average growth of profit $(15.94 \%)$ increased more than price $(11.78 \%)$ and fish catch $(4.15 \%)$ for the fishermen. Apart from mean growth of fish catch (4.15\%), which was the same for all, average price (11.84\%) and profit $(16 \%)$ for fishmongers was higher than that of fishermen. The highest catch, profit/revenue and price for both fishermen and fishmongers were recorded in 2005 and 2009 respectively.

The study found that the variables of catch, price and profit are interrelated in character. Accordingly, they could be conveniently categorised into catch-induced and price-induced growth in profit. Whereas the buying and selling prices (inflation for the fishery market) re- mained unchanged between 2001/2002 and $2004 / 2005$, growth in catch by $18.6 \%$ and $34.7 \%$ has induced near proportionate growth in profit by $18.5 \%$ and $34.7 \%$ for fishermen and fishmongers respectively.

The study revealed that demand for fish is localised and limited to few outlets. As a result, a change in supply marginally affects the equilibrium price hence, the near constant price of fish $/ \mathrm{kg}$ even when catch fluctuates. To a large extent, this is contrary to the position of FMSP/ MRAG (2006) that the amount of fish available to fishers influences the cost of fish and consequently, a reduction in revenue and/or income stream. Growth in the buying and selling price in 2001 by $28.8 \%$ and $55.9 \%$ has respectively induced an increase in profit by $22.8 \%$ and $50 \%$ for fishermen and fishmongers. Priceinduced growth in profit of fishermen and fishmongers was also observed in 2009. This provides an incentive for both biological and economic overfishing, particularly fisheries being managed under open access condition.

Users of reservoirs in the Upper East Region do not pay access fees or spend on their maintenance (IFAD, 2006). This was confirmed by the fishermen association that an attempt made by the Land Conservation and Smallholder Rehabilitation Projects (LACOSREP) to collect water user fees, among other responsibilities, did not receive District level and users' backing (such as bye-laws) for effective enforcement. It was only the fishmongers who helped to generate some kind of revenue, in the form of market tolls, as and when they sell fish in the market.

By this, it was only $36 \%$ of the sampled population and ancillary registered users of the reservoir fisheries who helped to generate local revenue. The total revenue collected by the catchment Districts in 2009 from the fishmongers was $\mathrm{GH} \phi 1,578.41$ ( $\mathrm{GH} \phi 1,352.46$ from Tono and $\mathrm{GH} \phi 225.95$ from Vea). In all, about $94.1 \%$ of the fishmongers paid between $\mathrm{GH} \not 5$ and $\mathrm{GH} \notin 26.99$ as annual tax while 5.8\% either paid $\mathrm{GH} \phi 27$ or more. 
Table 3: Catch-price and price-profit relationship

\begin{tabular}{|c|c|c|c|c|c|c|c|}
\hline \multicolumn{8}{|c|}{ Tono and Vea Reservoir Fishermen } \\
\hline Year & $\begin{array}{l}\text { Catch/tonne } \\
\text { (C) }\end{array}$ & $\begin{array}{l}\text { Growth } \\
\text { in }(C)\end{array}$ & $\begin{array}{l}\text { Price/kg } \\
\text { (GHф) }\end{array}$ & $\begin{array}{l}\text { Price/Tonne } \\
\text { (GHc) }\end{array}$ & $\begin{array}{l}\text { Growth } \\
\text { in }(P)\end{array}$ & $\begin{array}{c}\text { Profit } \\
\text { (R) }\end{array}$ & $\begin{array}{l}\text { Growth } \\
\text { in }(\mathbf{R})\end{array}$ \\
\hline 2000 & 66.47 & 0 & 0.2 & 200 & 0 & 13,294 & 0 \\
\hline 2001 & & & 0.35 & 350 & 55.9 & $21,920.50$ & 50 \\
\hline & 62.63 & -6 & & & & & \\
\hline 2002 & 75.4 & 18.6 & 0.35 & 350 & 0 & 26,390 & 18.5 \\
\hline 2003 & 87.55 & 14.9 & 0.4 & 400 & 13.4 & 35,020 & 28.3 \\
\hline 2004 & & & 0.35 & 350 & -13.4 & $50,883.00$ & 37.4 \\
\hline & 145.38 & 50.7 & & & & & \\
\hline 2005 & 205.67 & 34.7 & 0.4 & 400 & 13.4 & 82,268 & 48 \\
\hline 2006 & 59.65 & -123.8 & 0.45 & 450 & 11.8 & 26,843 & -112 \\
\hline 2007 & 87.09 & 37.8 & 0.5 & 500 & 10.5 & 43,545 & 48.4 \\
\hline 2008 & 68.29 & -24.3 & 0.55 & 550 & 9.5 & 37,560 & -14.8 \\
\hline 2009 & 100.72 & 38.9 & 0.65 & 650 & 16.7 & 65,468 & 55.6 \\
\hline Mean & 95.885 & 4.15 & 0.42 & 420 & 11.78 & 40,319 & 15.94 \\
\hline \multicolumn{8}{|c|}{ Tono and Vea Reservoir Fishmongers } \\
\hline Year & $\begin{array}{l}\text { Catch /tonne } \\
\text { (C) }\end{array}$ & $\begin{array}{l}\text { Growth } \\
\text { in }(C)\end{array}$ & $\begin{array}{l}\text { Price/kg } \\
(\text { GHc) }\end{array}$ & $\begin{array}{l}\text { Price/Tonne } \\
(\mathrm{GH})\end{array}$ & $\begin{array}{l}\text { Growth } \\
\text { in }(P)\end{array}$ & $\begin{array}{l}\text { Revenue } \\
\text { (R) }\end{array}$ & $\begin{array}{l}\text { Growth } \\
\text { in }(\mathbf{R})\end{array}$ \\
\hline 2000 & 66.47 & 0 & 0.3 & 300 & 0 & 19,941 & 0 \\
\hline 2001 & 62.63 & -6 & 0.4 & 400 & 28.8 & 25,052 & 22.8 \\
\hline 2002 & 75.4 & 18.6 & 0.45 & 450 & 11.8 & 33,930 & 30.3 \\
\hline 2003 & 87.55 & 14.9 & 0.5 & 500 & 10.5 & 43,775 & 25.5 \\
\hline 2004 & 145.38 & 50.7 & 0.55 & 550 & 9.5 & 79,959 & 60.2 \\
\hline 2005 & & & & & & & \\
\hline & 205.67 & 34.7 & 0.55 & 550 & 0 & $113,118.5$ & 34.7 \\
\hline 2006 & 59.65 & -123.8 & 0.75 & 750 & 31 & $44,737.5$ & -92.8 \\
\hline 2007 & 87.09 & 37.8 & 0.7 & 700 & 7.4 & 60,963 & 45.3 \\
\hline 2008 & 68.29 & -24.3 & 0.75 & 750 & 6.9 & $51,217.5$ & -17.4 \\
\hline 2009 & 100.72 & 38.9 & 0.85 & 850 & 12.5 & 85,612 & 51.4 \\
\hline Mean & 95.885 & 4.15 & 0.58 & 580 & 11.84 & $\mathbf{5 5 , 8 3 1}$ & 16 \\
\hline
\end{tabular}

Source: Irrigation Company of Upper Region (ICOUR, 2011) 
Economic Dimensions of Inland Fisheries...

Table 4: Dynamic interrelationship between tonnes bought, tax and profit ( $N=69)$

\begin{tabular}{lllll}
\hline & & Tonnes Bought & Tax Paid & $\begin{array}{l}\text { Profit Earned } \\
\text { (Fishmongers) }\end{array}$ \\
\hline Tonnes Bought & Pearson Correlation & 1 & $0.906^{* *}$ & $0.913^{* *}$ \\
& Sig. (2-tailed) & & .000 & .000 \\
\multirow{5}{*}{ Tax Paid } & $\mathrm{N}$ & 69 & 69 & 69 \\
& Pearson Correlation & $0.906^{* *}$ & 1 & $0.939^{* *}$ \\
& Sig. (2-tailed) & .000 & & .000 \\
Income Earned & $\mathrm{N}$ & 69 & 69 & 69 \\
& Pearson Correlation & $0.913^{* *}$ & $0.939^{* *}$ & 1 \\
& Sig. (2-tailed) & .000 & .000 & \\
& $\mathrm{~N}$ & 69 & 69 & 69 \\
\hline
\end{tabular}

**. Correlation is significant at the 0.01 level (2 tailed).

The correlation coefficient model predicts that tonnes purchased and tax paid and tonnes purchased and profit earned have a strong positive correlation coefficient of $0.906^{* *}$ and $0.913 * *$.

The respective coefficient of determination of $82.1 \%$ and $83.4 \%$ mean that $82.1 \%$ and $83.4 \%$ of changes in tax and profit could be explained by changes in tonnes of fish purchased. Tax and profit correlates more strongly than tax and tonnes purchased as it displayed a significant correlation coefficient of $0.939 * *$ and coefficient of determination of $88.2 \%$. This indicates that it was only $11.8 \%$ of changes in profit that could not be explained by the value of tax (Table 4). Taxes collected from appropriators of fish stock provides revenue for the common good especially, communities around fishing areas (Njaya, 2007). This opportunity is not being utilised by the Kassena Nankana District Assembly (KNDA) and Bongo District Assembly (BDA) as taxes from fishermen and fishmongers did not reflect in their revenue estimates. But FMSP/MRAG (2006) acknowledged that the revenue stream that could be generated from fishery has direct relation with catch and price. This was affirmed by the current study as the tax and profit variables were strongly correlated with tonnes.

\section{CONCLUSION}

The study provides enough evidence that Tono and Vea reservoirs have provided and continue to provide a livelihood strategy devoted to catch fish for employment, revenue and income generation as well as fish food for home consumption. The economic variables of income, employment, revenue and/or rent are greatly influenced by the nature of use right- open access fishery- as it determines fishers' density, catch, effort, maximum economic and sustainable yields. In addition, accessibility affects the level of cooperation in terms of payment of user fees, compliance with effort and gear restriction as well as observation of closed season. The concomitant ramification of this correlation is that, the economic dimension of the nature-based resource (fish) is not only related to the quantity harvested but also how appropriate the approach of exploitation has been applied. The connectivity between Tono and Vea reservoir fisheries and income, employment, and revenue was found to be at risk as the key determinant of economic value of the fishery (that is, fish) has been recording fluctuating trends. The underlying tenet of these argument is to recognise the value of river fisheries and the ecosystem for sustaining rural livelihoods as well as a need to harmonise fisheries policies 


\section{Okrah and Agyeman}

and legislation (especially bye-laws) with other natural resource policies that focus on the 'livelihood approach' for an improved well being of the riparian communities.

\section{POLICY RECOMMENDATIONS}

The study has examined the employment, income and revenue dimensions of the inland fisheries of Tono and Vea reservoirs. The key findings that have emerged from the foregoing analysis have implications for direct policy intervention, regulatory enforcement and review of the inland fishery sector by MoFA, ICOUR, DAs and catchment communities of the reservoirs:

- The study revealed that irrespective of institutionalised modern management over the Tono and Vea fisheries, open access is still the dominant mode of accessing the fish stock. Whereas entry into a commonpool resource is assumed to be influenced by price and the expected returns, the case of Tono and Vea portrayed a situation of continuous appropriation even below maximum economic yield (MEY). Since the type of ownership affect the stream of benefits to users, the use right should be well defined.

- The fact that catch-induced and priceinduced growth influenced the profit of both fishermen and fishmongers, there was the incentive to increase fishing effort and quantity of gear. Over-exploitation of the fishery resources will work against the objectives of providing livelihood and employment. Therefore, there is the need for enforcement of effort restriction and gear quota policies to increase landings - within the concept of 'sustainable development'enhanced fishery employment capacity and economic profitability.

- The catch-price and price-profit relationship computed showed that, to a large extent, continuous provision of sustainable fishery employment will be influenced by conservation of the resource (fish). Fish and its volume are positively related to profit and/or income (as it is assumed that an increased catch will translate into higher profit and/or income) but since fish is an ecological resource, its continuous exploitation for enhanced profit is affected by genetic, species and ecosystem diversities and conservation. Therefore, there should be multidimensional water use planning that has to balance human requirements against protection of the environment and biodiversity.

- Fishery revenue that could have been raised to provide other 'public goods', was not part of revenue profile of the study Districts. Apart from leaving the fishermen out of the tax net, the fishmongers only contribute to revenue through the payment of market tolls. Thus, out of the 192 sampled population, it was only $36 \%$ (69) that helped to raise revenue. This implies that there is a condition of revenue leakage from the inland fishery sector of the Tono and Vea reservoirs. This call for the strategy of profiling the revenue sources in the catchment Districts which will give a fair knowledge about revenue potentials of the fishery and what could be done to harness the potential for sustainable revenue collection. It is significant to note that, payment of user/access fees will contribute towards maintenance of the reservoirs and other infrastructures for enhanced harvesting of fish.

\section{REFERENCES}

Allan, J. D., Abell, R., Hogan, Z., Revenga, C., Taylor, B. W. Welcomme, R. L. and Winemiller, K. (2005). Overfishing of inland waters. Bioscience 55 (12): 1041-51.

Allison, E. H., Andrew, N. L. and Oliver, J. (2004). Effects of climate change on the sustainability of capture and enhancement fisheries important to the poor: Analysis of the vulnerability and adaptability of fisherfolks 
Economic Dimensions of Inland Fisheries... 138

living in poverty. MRAG Group Ltd, London, U.K.

Allison, E. H., Andrew, N. L. and Oliver, J. (2007). Enhancing the resilience of inland fisheries and aquaculture systems to climate change. ICRISAT, Vol. 4(1): 3-14.

Baland, J. M. and Platteau, J. P. (2000). Halting degradation of natural resources. Is there a role for rural communities? FAO, Rome.

Béné, C. (2006). Small-scale fisheries: Assessing their contribution to rural livelihoods in developing countries. FAO fisheries circular 1008. FAO, Rome.

Béné, C. (2007). Diagnostic study of the Volta Basin fisheries. Volta Basin focal project report, No.6, World Fish Centre, Cairo.

COFAD (2002). Traditional inland fisheries management and enhancement systems in Sub-Saharan Africa and their potential for development. Deutsche Gesellschaft für Technische Zusammenarbeit (GTZ), Eschborn-Germany.

FMSP/MRAG (2006). Fisheries and poverty reduction. FMSP policy brief 1, available at www.fmsp.org.uk on 17/12/2009.

Ghana Statistical Service (2000). Population and Housing Census, Ghana Statistical Service, Accra.

Hartmann, W., Dugan, P., Funge-Smith, S., Hortle, K. G., Kuemlangan, B., Lorenzen, K., Marmulla, G., Mattson, N. and Welcomme, R.L. (2004). People and fisheries management. In: Proceedings of the second international symposium on the management of large rivers for fisheries Vol. 1, Welcomme, R.L. \& Petr, T. [Eds], FAO regional office for Asia and the Pacific, Bangkok, Thailand. RAP Publication 2004/16, p. 61-92.

IFAD (2006). Upper East Region land conser- vation and smallholder rehabilitation project (LACOSREP) report. No 5, available at http://www.ifad.org/governance/index.htm on $20 / 02 / 2010$

Irrigation Company of Upper Region [ICOUR] (1995). ICOUR information handbook. ICOUR Ltd, Ghana.

Irrigation Company of Upper Region [ICOUR] (2011). Report on record of fish catch from Tono and Vea reservoirs. ICOUR Ltd, Ghana.

Liebe, J., Van de Giesen, N. and Andreini, M. (2005). Estimation of small reservoir storage capacities in a semi-arid environment: A case study in the Upper East Region of Ghana, available at www.smallreservoirs.org on 17/01/2010.

Lorenzen, K., Nguyen Khoa, S., Garaway, C., Arthur, R., Kirkwood, G., Chamsingh, B., Litdamlong, D., Innes-Taylor, N. and Siebert, D. (2000). Impacts of irrigation and aquaculture development on small-scale aquatic resources. Final technical report, DFID project R7235. Imperial College, London.

Ministry of Food and Agriculture (2002). Food and Agriculture sector development policy, Ghana.

Ministry of Food and Agriculture (2008). Information on fisheries in Ghana. MoFA/ directorate of fisheries publication. Accra-Ghana.

Neiland, A. E. and Béné, C. (2003). Review of river fisheries valuation in West and Central Africa. A contribution to the water ecosystems and fisheries. Review workshop, World Fish Centre, Cairo.

Njaya, F. (2007). Governance challenges for the implementation of fisheries comanagement: Experiences from Malawi. International Journal of the Commons, 1(1): 139-153. 


\section{Okrah and Agyeman}

Sarch, M. T. and Allison, E. H. (2000). Fluctuating fisheries in Africa's inland waters: Well adapted livelihoods, maladapted management. Proceedings of the 10th international conference of the institute of fisheries economics and trade, Corvallis, Oregon. July 914th 2000.

Von Sarnowski, A. (2004). The artisanal fisher- ies of Lake Albert and the problem of overfishing. Johannes Gutenberg Unviverität Mainz, Germany.

World Fish Centre (2008). Tropical river fisheries valuation: Establishing economic value to guide policy. World Fish Centre, Penang, Malaysia. 